\title{
Determination and analysis of the economic optimum culling strategy in swine breeding herds in Western Europe and the USA
}

\author{
G. J. SCHOLMAN \& A. A. DIJKHUIZEN* \\ Department of Farm Management, Wageningen Agricultural University, Hollandseweg 1, \\ NL 6706 KN Wageningen, Netherlands
}

Received 24 September 1988; accepted 19 January 1989

\begin{abstract}
The optimum sow culling strategy in 6 different countries was determined and compared using the same economic replacement model (PorkCHOP). The calculated optimum lifespan for sows was found to vary considerably between the countries. The ratio between slaughter value of culled sows and cost of replacement gilts turned out to be a major determinant of the optimum strategy.
\end{abstract}

Keywords: economic modelling, sows, culling strategy

\section{Introduction}

Usually, sows are culled because of health and fertility problems or inadequate production and reproductive performance (Kroes \& van Male, 1979; van der Steen, 1984). Particularly in the latter cases, culling decisions are based on economic considerations. Those sows are replaced not because they are no longer able to produce in a biological sense, but because replacement gilts are expected to yield more (Dijkhuizen et al., 1986).

To optimize these culling decisions, an economic sow replacement model was developed, initially for application to US herd conditions (Dijkhuizen et al., 1986). The model allows the user to enter data for all the variables considered, and thus can easily be adjusted to individual farm conditions world wide.

In this paper the model is used to determine and compare the economic optimum sow culling strategy in 5 West European countries and the USA.

\section{Material and methods}

The Netherlands, Belgium, Britain, Denmark, West Germany and the United

* Corresponding author. 
Table 1. Herd performance data from the collaborating countries.

\begin{tabular}{lcccccc}
\hline & NET & BEL & BRI & DEN & GER & USA \\
Pigs weaned per sow per year & 18.2 & 15.8 & 20.5 & 19.6 & 17.4 & 19.1 \\
Annual replacement rate sows (\%) & 47 & 57 & 39 & 49 & 50 & 59 \\
Market price feeder pigs (Dfl.) & 110 & 118 & 93 & 132 & 126 & 117 \\
Slaughter value culled sows (Dfl.) & 508 & 470 & 426 & 559 & 482 & 486 \\
Costs of replacement gilts (Dfl.) & 595 & 606 & 661 & 594 & 493 & 697 \\
\hline
\end{tabular}

${ }^{1} \mathrm{NET}=$ The Netherlands, $\mathrm{BEL}=$ Belgium, BRI $=$ Britain, DEN $=$ Denmark, GER $=$ West Germany and USA $=$ United States of America.

States of America were involved in the project. Swine specialists in each of the countries provided parity-specific input values for sow removal probability, litter size, piglet mortality, feed consumption, live weight and slaughter price of culled sows. Additionally the cost of replacement gilts was specified. The data reflect typical commercial swine breeding herds, with standard management.

In Table 1, some major input values are summarized and presented on a herd basis. Britain ranked highest for the number of pigs weaned per sow per year (defined as pigs born alive minus total pig mortality) and achieved the lowest annual replacement rate for sows, but it was faced with the lowest market price for feeder pigs and the most unfavourable ratio between slaughter price of culled sows and cost of replacement gilts. The latter ratio was by far the most favourable in Denmark and West Germany.

For each of the different countries, the economic replacement model determines a sow's optimum lifespan and calculates the net present value of the total extra profits to be expected from trying to keep her until that optimum parity instead of replacing her immediately, taking into account the risk of premature removal of retained sows. This total extra profit, called Retention Pay-Off (RPO), is calculated at the time a sow is weaned. The RPO is an economic index, which makes it possible to rank sows in terms of future profitability. A value below zero means that replacement is the most profitable choice. By relating the value of the RPO index and the calculated financial loss of a delay in conception, an indication is given of the maximum allowable number of days to (re-)breed when sows fail to conceive.

\section{Results}

In the Netherlands, Belgium, Britain and the USA, average producing sows still have a - small - positive RPO index after 9 parities, indicating an economic optimum lifespan of 10 parities (Table 2). In Denmark and West Germany, however, the optimum lifespan turned out to be 6 and 7 parities, respectively. Also the RPO index for their younger sows is the lowest. So, from an economic point of view, poor-producing sows in both these countries have to be culled earlier as well. Additional calculations showed that sows producing $50 \%$ below average, for instance, should be culled before their second parity, whereas in Belgium such a sow has an economic optimum lifespan of 4 parities. 
Table 2. Optimum replacement policy for average producing sows.

\begin{tabular}{lllrrrrrr}
\hline & & NET $^{1}$ & BEL & BRI & & DEN & GER & USA \\
RPO index (Dfl.) after parity & 1 & 296 & 354 & 344 & 212 & 176 & 366 \\
& 2 & 267 & 306 & 309 & 208 & 162 & 345 \\
& 3 & 222 & 245 & 245 & 141 & 118 & 278 \\
& 5 & 125 & 129 & 129 & 12 & 38 & 133 \\
& 7 & 48 & 50 & 48 & - & - & 54 \\
& 9 & 10 & 7 & 1 & - & - & 19 \\
Costs per extra open day (Dfl.) & & 3.71 & 3.35 & 3.33 & 4.80 & 4.13 & 4.80 \\
\hline
\end{tabular}

1 See Table 1.

A delay in conception reduces annual income since fewer pigs can be sold, although some variable (feed) costs can be saved. The calculated loss per extra open day turned out to be the highest in Denmark and the USA and the lowest in Belgium and Britain, as shown in Table 2. By relating the RPO index and the calculated loss per extra open day, it is indicated that third-parity sows with an average production level in Denmark and West Germany, for instance, should conceive within 30 days after weaning, whereas in Belgium and Britain (re-)breeding is economically worthwhile even for more than 70 days.

Finally, a sensitivity analysis was carried out, which showed a strong positive correlation between feeder pig prices and the costs per open day. On the other hand, these prices had only a minor effect on the optimum lifespan and the RPO index. The optimum lifespan was especially dependent on the ratio between the slaughter price of culled sows and the cost of replacement gilts, as was found in previous work (Dijkhuizen et al., 1986). The more favourable this ratio, the shorter the optimum herd life. This was true for all the countries concerned.

\section{Concluding remarks}

By using identical methodology and a standard computer model, it was possible to quantify the actual differences in optimum sow culling strategy between countries. Further research would be of interest to see in what ways the farmers' actual decisions for individual sows in each of the collaborating countries reflect the calculated differences in modelling results.

\section{References}

Dijkhuizen, A. A., R. S. Morris \& M. Morrow, 1986. Economic optimization of culling strategies in swine breeding herds, using the 'PorkCHOP computer program'. Preventive Veterinary Medicine 4: 341-353.

Kroes, Y. \& J. P. van Male, 1979. Reproductive lifetime of sows in relation to economy of production. Livestock Production Science 6: 179-183.

Steen, H. A. M. van der, 1984. Prediction of future value of sow productivity. Proceedings European Association for Animal Production, Den Haag. 
This synopsis is based on a doctoral thesis entitled 'Vaststelling en analyse van het optimale vervangingsbeleid bij zeugen in West-Europa en de Verenigde Staten' by G. J. Scholman, Department of Farm Management, Wageningen Agricultural University, Wageningen, 1988. 67 pp., 2 figs., 14 tables, 34 refs., Dutch. Available as paper copy (order R089, f10 including postage) at: NARD, clo Pudoc, P.O. Box 4, 6700 AA Wageningen (telex 45015 blhwg nl). 